\title{
Vitamin C intake and plasma ascorbic acid concentration in adolescents
}

\author{
BY P. M. FINGLAS, ANGELA BAILEY, A. WALKER, JULIE M. LOUGHRIDGE, \\ A. J. A. WRIGHT AND SUSAN SOUTHON \\ AFRC Institute of Food Research, Norwich Laboratory, Norwich Research Park, Colney, \\ Norwich NR4 $7 U A$
}

(Received 8 July 1991-Accepted 8 May 1992)

\begin{abstract}
The relationship between vitamin $C$ intake and status was investigated in a group of adolescents (13-14 years old). Dietary intakes were assessed using a $7 \mathrm{~d}$ weighed dietary record method, coupled with the collection of duplicate diets. Vitamin $C$ intakes calculated using food composition tables were compared with values obtained by direct analysis of duplicate diets. Vitamin $C$ status was judged via measurement of plasma ascorbic acid (AA) concentration in blood samples taken after a 12-15 h fast. The relationship between calculated and analysed vitamin $\mathrm{C}$ intake and plasma $\mathrm{AA}$ concentration was examined. Average daily calculated vitamin $C$ intakes, for the group $(n 54)$ as a whole over a $7 \mathrm{~d}$ period, gave a good estimate of intake, as judged by prompt analysis of duplicate diets. However, analysed $v$. calculated intakes were significantly different for approximately one-third of subjects when data were examined on an individual basis. Large discrepancies between analysed and calculated values could not be accounted for on a food group basis. In all but two individuals, calculated vitamin $\mathrm{C}$ intake was in excess of the new reference nutrient intake (RNI, part of the new daily reference values (Department of Health and Social Security, 1991)) of $40 \mathrm{mg}$ and all plasma AA concentrations were well above those used to indicate even a moderate risk of deficiency. A relationship between vitamin $C$ intake and plasma $A A$ was observed for both males $(n 19)$ and females $(n$ 35). However, the relationship was much stronger for males who showed a wider range of both intake and plasma $A A$ values.
\end{abstract}

Vitamin C: Plasma ascorbic acid: Adolescents

Vitamin $\mathrm{C}$ has long been known as an essential nutrient to man. In addition to the more well-established biochemical roles for the vitamin (Bates, 1981), recently ascorbic acid (AA) has also been implicated in the immune response, allergic reactions and leucocyte function (Sauberlich, 1981), and the daily intake required to maintain optimal health remains a matter of controversy. Definition of the relationship between diet and health is an extremely complex area requiring detailed and accurate information on dietary intake and an understanding of the relationship between intake and biochemical/physiological processes which may influence the well-being of the individual. Concern for the role that vitamin C may play in degenerative diseases of aging (Frei et al. 1988) has stimulated the study of vitamin $C$ intake and status, and the relationship between them, in the elderly (Jacob et al. 1988; Vanderjagt et al. 1987, 1989), but information for younger individuals is more limited, although it seems reasonable to assume that early nutrition may affect morbidity in later life.

As part of a larger study of micronutrient intake and status in adolescents, the relationship between vitamin $\mathrm{C}$ intake and plasma $\mathrm{AA}$, as an indicator of status, was investigated. Studies of this kind rely heavily on the accuracy of dietary information obtained and the subsequent calculation of specific nutrient intake, hence detailed 
consideration was given to the assessment of vitamin $\mathrm{C}$ intake for the group of subjects and for individuals within the group. Vitamin $\mathrm{C}$ intakes from $7 \mathrm{~d}$ weighed dietary records were calculated from food composition tables and compared with values obtained by direct analysis of duplicate diets. Since many studies rely upon food table data, direct analysis being impossible or impractical, calculated $v$. analysed vitamin $\mathrm{C}$ intake values were examined on a daily food group basis, as well as a combined $7 \mathrm{~d}$ basis, in an attempt to identify the causes of major discrepancies.

\section{MATERIALS AND METHODS}

Subjects

The study was subjected to ethical approval by the Institute Ethics Committee before recruitment.

Subjects, 13-14 years, were recruited from two local authority schools in the provincial city of Norwich, Norfolk. Sixty-one subjects were recruited. Seven subjects withdrew during the course of the study leaving a total of fifty-four subjects, thirty-five girls and nineteen boys. The median (range in parentheses) age, height and weight of the girls and boys respectively was; age $13.8(13.3-14.3), 13.6(13.2-14.3)$ years; height $1.58(1.50-1.74)$, $1.62(1 \cdot 42-1 \cdot 87) \mathrm{m}$; weight $51 \cdot 2(38 \cdot 5-62 \cdot 5), 46 \cdot 7(33 \cdot 1-68 \cdot 0) \mathrm{kg}$. Median heights and weights for the subjects were similar to the 50 th percentile values calculated by the National Centre for Health Statistics for this age-group (Thomas, 1988).

\section{Measurement of intake}

Each subject kept a written weighed record of everything they ate and drank every 6th day for 7 weeks (Black et al. 1984) between 1 November and 21 December. On each of these days the subjects also collected duplicate portions of all food and drink consumed.

A set of Salter scales (model no. 2001; Salter Homewares Ltd, Tonbridge, Kent; maximum capacity $2 \mathrm{~kg}$ and accurate to $2 \mathrm{~g}$ ), a supply of intake record sheets, a small notebook and acid-washed plastic food/drink containers were given to each subject. An instruction booklet giving details of how to perform dietary collections and complete dietary record sheets were also provided, together with a personal timetable of recording/collection dates. In addition, a fieldworker visited each home to demonstrate the use of the dietary scales and completion of record sheets. Subjects were advised to provide as much information as possible on brand and preparation of foods and carefully note any wastage. Wrappers and packaging were retained as a potentially useful source of information. Instruction was given on how to record composite foods, ready meals and foods eaten outside the home. If a subject could not provide a duplicate portion of foods consumed outside the home they were asked to describe the food/meal as fully as possible. Duplicate items were then purchased by the fieldworker and added to the day's collection. Catering staff at each school put aside duplicate portions for those subjects who had school meals. These were collected and weighed shortly after the end of their dinner break and the appropriate recipes were obtained. Subjects who took packed lunches to school prepared a duplicate lunch and later removed any items which had not been consumed before the meal was added to the day's collection.

\section{Diet collection and preparation}

The duplicate food and drink containers were kept at $-18^{\circ}$ in a domestic freezer until they were collected early the following day, along with the dietary record sheets. The information was checked in the presence of the subject to ensure that all the necessary detail had been provided. 
The completed duplicate diets were homogenized immediately after collection using a stainless-steel blender (R. W. Jennings Ltd, Nottingham, Notts). Distiller water was added to aid homogenization if necessary. The weight of water added and the weight of the homogenized diet was recorded. Sub-samples $(100 \mathrm{~g})$ were taken immediately for vitamin $\mathrm{C}$ (total ascorbate) analysis. In preliminary trials homogenized mixed diet samples, stored at $-18^{\circ}$ for $6 \mathrm{~d}$, showed only 5-10\% losses of total vitamin $\mathrm{C}$ when compared with values obtained immediately after preparation. This indicated that the sampling scheme used in the study gave realistic measurements of dietary vitamin $\mathrm{C}$ content.

\section{Blood collection and preparation}

Fasting ( $12 \mathrm{~h}$ ) venous blood samples were obtained between 9 November and 7 December during the period of dietary assessment but not on or immediately following a day of dietary recording. Fresh (within $1 \mathrm{~h}$ of collection) whole heparinized blood $(1.5 \mathrm{ml})$ was centrifuged at $8000 \mathrm{~g}$ for $4 \mathrm{~min}$. The plasma was removed and stored on ice for approximately $10 \mathrm{~min}$ before analysis.

\section{Vitamin $C$ analysis}

The method used was essentially that of Behrens \& Madere (1987). All steps were performed under non-u.v. lighting (Gold Fluorescent; Thorn, London).

AA and dehydroascorbic acid were extracted from duplicate portions $(20 \mathrm{~g})$ of freshly prepared diets by homogenizing samples for $2 \mathrm{~min}$ in ice-cold metaphosphoric acid solution $(10 \mathrm{ml}, 85 \mathrm{~g} / 1$ distilled water, made up fresh daily). Homogenates were made up to $100 \mathrm{ml}$ with distilled water, mixed well and placed on ice. Samples $(10 \mathrm{ml})$ were centrifuged at $1500 \mathrm{~g}$ for $10 \mathrm{~min}$ at $4^{\circ}$, filtered (Whatman no. 541), the first $1 \mathrm{ml}$ or so of supernatant fraction being discarded and the remaining filtrate kept for HPLC analysis.

AA standard solutions, $0-40 \mu \mathrm{g} / \mathrm{ml}$ in metaphosphoric acid $(8.5 \mathrm{~g} / 1)$, were prepared freshly on each day of analysis and stored on ice before use. Portions $(1 \mathrm{ml})$ of sample filtrates and standard solutions were diluted with $300 \mu \mathrm{l}$ freshly prepared DL-homocysteine solution, $10 \mathrm{~g} / 1$ in dipotassium phosphate buffer $\left(2.58 \mathrm{M}-\mathrm{K}_{2} \mathrm{HPO}_{4}\right.$ in distilled water, adjusted to $\mathrm{pH} 9.8$ using concentrated $\mathrm{KOH}$ ), raising the $\mathrm{pH}$ to 7.7 (Hughes, 1956). Samples were mixed well and left at room temperature to allow the reduction of dehydroascorbic acid to AA. After $30 \mathrm{~min} 3.7 \mathrm{ml}$ metaphosphoric acid $(8.5 \mathrm{~g} / 1)$ was added to stop reduction and stabilize the ascorbic acid for the HPLC determination of total vitamin $\mathrm{C}$.

Portions $(300 \mu \mathrm{l})$ of fresh ice-cold plasma were added to equal volumes of ice-cold metaphosphoric acid ( $17 \mathrm{~g} / \mathrm{l}$ in distilled water), mixed and centrifuged at $8800 \mathrm{~g}$ for $4 \mathrm{~min}$. Duplicate portions $(100 \mu \mathrm{l})$ of sample supernatant fractions and standard ascorbic acid solutions (freshly prepared, $0-10 \mu \mathrm{g} / \mathrm{ml}$ ) were pipetted into separate amber vials together with $30 \mu \mathrm{l}$ dipotassium phosphate buffer $(2.58 \mathrm{M}, \mathrm{pH} 9.8)$ and allowed to stand at room temperature for $30 \mathrm{~min}$ before dilution with $370 \mu \mathrm{l}$ metaphosphoric acid $(8.5 \mathrm{~g} / \mathrm{l})$ and subsequent HPLC analysis for AA concentration.

$\mathrm{AA}$ in the diet and plasma samples was determined using the same HPLC system. A Shimadzu SIL-9A auto-injector (Shimadzu Corporation, Kyoto, Japan) was used to inject sample and standard solutions $(20 \mu 1)$ onto a $250 \mathrm{~mm} 4.6 \mathrm{~mm}$ i.d. Apex ODS analytical column $(5 \mu \mathrm{m})$ (Hichrom Ltd, Reading, Berks) protected by a ODS guard column $(40 \mu \mathrm{m})$ (Anachem Ltd, Luton, Beds). The mobile phase was prepared by mixing a sodium acetate solution $(80 \mathrm{~mm}$ sodium acetate adjusted to $\mathrm{pH} 4.6$ followed by addition of $0.150 \mathrm{~g}$ metaphosphoric acid and $0.129 \mathrm{~g}$-octylamine/1) and methanol $(90: 10, \mathrm{v} / \mathrm{v})$. The mobile phase was pumped at a flow rate of $1 \mathrm{ml} / \mathrm{min}$ at ambient temperature using a SA3410 solvent delivery system (Severn Analytical, Luton, Beds). AA was detected electro- 
chemically using an ampterometric detector (Biotech Instruments, Luton, Beds) fitted with a glassy carbon and $\mathrm{Ag} / \mathrm{AgCl}$ reference electrode set at a potential of $+0.6 \mathrm{~V}$ and range $500 \mathrm{nA}$. Data were collected using a PU4850 CCC Data Station (Pye Unicam, Cambridge, Cambs) and concentrations of AA calculated by comparison of peak areas. Detector responses to calibration standards were linear in the range $0-50 \mu \mathrm{g} \mathrm{AA} / \mathrm{ml}$. Total ascorbate contents of diets were expressed as $\mu \mathrm{g} / 100 \mathrm{~g}$ homogenate and vitamin $\mathrm{C}$ intakes calculated as $\mathrm{mg} / \mathrm{d}$ for each subject; a total of 378 duplicate diets were analysed. AA in plasma was calculated as $\mu \mathrm{mol} / 1$; a total of fifty-four plasma samples were analysed. Recoveries of added AA or dehydroascorbic acid from diet samples were 104.4 $(102 \cdot 4-106.9) \%(n 7)$ and $101 \cdot 7(94 \cdot 5-112 \cdot 1) \%(n 6)$ respectively, and the recovery of added AA from plasma was $100 \cdot 1(97 \cdot 1-103 \cdot 9) \%(n 7)$. Intra-assay repeatabilities between duplicate extractions, expressed as mean percentage errors, were $0.95 \pm 0.67 \%(n 10)$ for total vitamin $\mathrm{C}$ in diet samples and $1 \cdot 12 \pm 0 \cdot 54 \%(n 10)$ for plasma $\mathrm{AA}$.

\section{Calculation of vitamin $C$ and energy intake}

Dietary records were coded using McCance \& Widdowson's The Composition of Foods (Paul \& Southgate, 1978), together with the Immigrant Foods Supplement (Tan et al. 1985), additional foods (Wiles et al. 1980), Cereals \& Cereal Products (Holland et al. 1988), Milk Products and Eggs (Holland et al. 1989) and unpublished compositional values (J. M. Loughridge and A. Walker, AFRC Institute of Food Research) consisting of data collected from previous dietary intake studies on portion sizes, standard weight of branded foods and composition of composite dishes. Missing food quantities were obtained using Food Portion Sizes (Crawley, 1988). Total daily vitamin C intakes (mg/d) and energy intakes $(\mathrm{kJ} / \mathrm{d})$ were calculated using the Institute of Food Research food composition database. Average intakes of vitamin $\mathrm{C}$ were also expressed according to food group by means of a spreadsheet computer program (Excel, version 2.1, 1988; Microsoft Corporation, Readmond, USA).

\section{Energy analysis}

Bomb calorimetry was performed on freeze-dried samples of diet and metabolizable energy estimated as follows: analysed energy (metabolizable energy) $/ \mathrm{d}=(\mathrm{Bomb}$ energy $(\mathrm{kJ} / \mathrm{d}) \times 0.95)-(\mathrm{N}(\mathrm{g} / \mathrm{d}) \times 30 \mathrm{~kJ})$; Miller \& Payne $(1959)$.

\section{Statistical analysis}

Before statistical comparison by unpaired $t$ test or regression analysis, both analysed and calculated vitamin $C$ intakes were $\log _{10}$-transformed to normalize distribution. Vitamin $C$ intake data were not transformed for paired $t$ tests since the differences between paired data were normally distributed.

Statistical comparisons were performed using Student's paired or unpaired $t$ test, as appropriate. The statistical analysis used is indicated in each table of results. The relationship between analysed and calculated vitamin $C$ intake $\left(\log _{10}\right)$, and between vitamin $\mathrm{C}$ intake $\left(\log _{10}\right)$ and plasma AA was established using regression analysis.

\section{RESULTS}

Vitamin $C$ and energy intake

Energy intake (from direct analysis of duplicate diets) and vitamin $C$ intake (both calculated and analysed) for female and male subjects are shown in Table 1 . The mean analysed energy intake for males was $26 \%$ higher $(P<0.001)$ than that for females, whilst 
Table 1. Energy intake (analysed ), fasting plasma ascorbic acid concentration $(P A A)$ and vitamin $C$ intake (analysed $\dagger$ and calculated $\$$ ) for thirty-five female and nineteen male adolescents $(13-14$ years)

(Values are means with their standard errors)

\begin{tabular}{|c|c|c|c|c|c|c|c|c|c|}
\hline & & \multicolumn{4}{|c|}{9} & \multicolumn{4}{|c|}{$3^{3}$} \\
\hline & & Mean & SEM & GM & Range & Mean & SEM & GM & Range \\
\hline Energy $(\mathrm{kJ} / \mathrm{d})$ & Analysed & $7364^{* * *}$ & 222 & & $4548-10950$ & 9245 & 354 & 69 & $64-12719$ \\
\hline $\operatorname{PAA}(\mu \mathrm{mol} / \mathrm{l})$ & - & 77 & 4 & & $37-143$ & 81 & 9 & & $39-207$ \\
\hline \multirow{2}{*}{$\begin{array}{l}\text { Vitamin C intake } \\
\left(\log _{10} \mathrm{mg} / \mathrm{d}\right) \S: \\
\text { (all subjects): }\end{array}$} & Analysed & $1.902^{*}$ & 0.025 & 80 & $43-153$ & $2 \cdot 038$ & $0 \cdot 047$ & 109 & $49-246$ \\
\hline & Calculated & $1.811^{*}$ & $0 \cdot 041$ & 65 & $19-182$ & 1.979 & 0.072 & 95 & $24-428$ \\
\hline \multirow{2}{*}{$\begin{array}{l}\text { Excluding subjects } \\
\text { who took } \\
\text { supplements } \|\end{array}$} & Analysed & $1.898^{*}$ & 0.026 & 79 & $43-153$ & $2 \cdot 000$ & $0 \cdot 044$ & 100 & $49-211$ \\
\hline & Calculated & $1 \cdot 810$ & $0 \cdot 042$ & 65 & $19-182$ & 1.912 & 0.061 & 82 & $24-171$ \\
\hline
\end{tabular}

GM, geometric mean.

Mean values were significantly different from those for male subjects (unpaired $t$ test): ${ }^{*} P<0 \cdot 05, * * * P<$ $0 \cdot 001$.

$\uparrow$ Obtained by direct analysis of duplicate diets.

\$ Obtained using food composition tables.

$\S$ There was no significant difference between analysed and calculated values within sexes (paired $t$ test, untransformed data; see p. 566).

4 One female and two males who took routine supplements excluded.

the geometric means of analysed and calculated vitamin $\mathrm{C}$ intakes were 36 and $46 \%$ higher $(P<0.05)$ respectively in the boys; 9 and $16 \%$ higher when expressed in terms of energy intake.

Calculated and analysed vitamin $\mathrm{C}$ intake values for male and female subjects were not significantly different (Table 1). Mean values (with their standard errors) for analysed and calculated intakes were 84.2 (SE 4.7) and 74 (SE 6.9) $\mathrm{mg} / \mathrm{d}$ respectively for girls, and 121.4 (SE 13.3) and 121.2 (SE 21.9) $\mathrm{mg} / \mathrm{d}$ respectively for boys. Vitamin C intake data in Table 1 are $\log _{10}$-transformed to normalize distributions and, therefore, geometric means are presented. There was a greater range of intake in males which was largely due to one subject who routinely took a vitamin $C$ supplement which contributed $357 \mathrm{mg} / \mathrm{d}$ (according to product information) over and above dietary sources. Two other subjects, one male and one female, also supplemented their diet with vitamin $\mathrm{C}$; the supplements providing (according to product information) an average of 12.8 and $21.4 \mathrm{mg}$ vitamin $\mathrm{C} / \mathrm{d}$ respectively. These supplements were included in duplicate diet collections. Intake values which exclude subjects taking supplemental sources of vitamin $\mathrm{C}$ are also included in Table 1.

The correlation between mean $7 \mathrm{~d}$ analysed and calculated vitamin $\mathrm{C}$ intakes for boys was $r 0.75\left(P<0.001\right.$; analysed vitamin $\mathrm{C}\left(\log _{10}\right)=1.07+0.490$ calculated vitamin $\mathrm{C}$ $\left.\left(\log _{10}\right)\right)$ and for girls was $r 0.72\left(P<0.001\right.$; analysed vitamin $C\left(\log _{10}\right)=1 \cdot 11+0.435$ calculated vitamin $\left.C\left(\log _{10}\right)\right)$. These regressions were statistically the same for both sexes and could be expressed as a common regression $r 0.76(P<0.001$; analysed vitamin $\mathrm{C}$ $\left(\log _{10}\right)=1.03+0.490$ calculated vitamin $C\left(\log _{10}\right)$; Fig. 1). However, the association between analysed and calculated values was reduced when data were compared on a daily basis for the total recording period ( $r 0.41$ and 0.58 for girls and boys respectively) and 


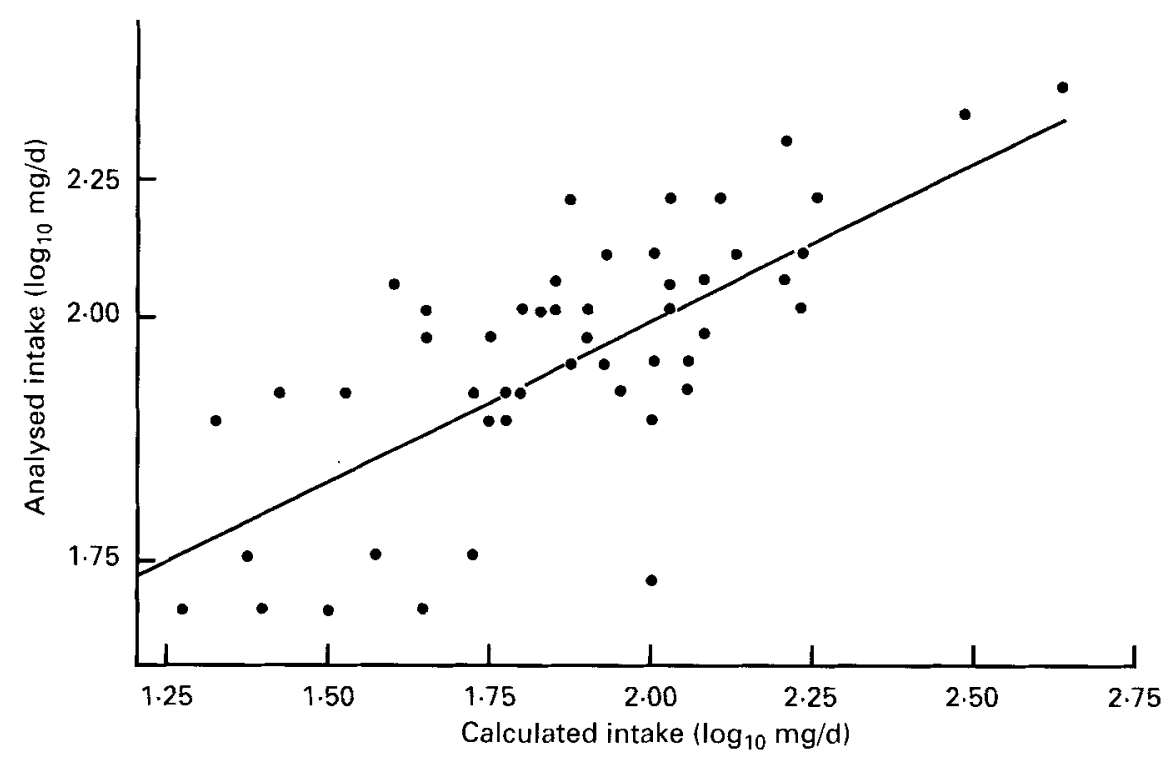

Fig. 1. Correlation between mean $7 \mathrm{~d}$ analysed and calculated vitamin $\mathrm{C}$ intake for fifty-four adolescents (13-14 years $) ; r=0.76(P<0.001)$ : Data were $\log _{10}$ transformed to normalize distribution. Mean analysed vitamin $\mathrm{C}$ $\left(\log _{10}\right)=1 \cdot 03+0 \cdot 490$ mean calculated vitamin $C\left(\log _{10}\right)$. For details of subjects and procedures, see pp. $564-566$.

Table 2. Comparison of analysed $(A)$ and calculated $(C)$ vitamin $C$ intake values (within subject) over $7 d$ for fifty-four subjects (nineteen male, thirty-five female) and a comparison of analysed and calculated intake on each separate day (between subject)

(Comparison of untransformed intakes by Student's paired $t$ test)

\begin{tabular}{|c|c|c|}
\hline & 9 & $\delta^{2}$ \\
\hline \multicolumn{3}{|c|}{ Within subjects $\dagger$} \\
\hline $\mathrm{A}=\mathrm{C}$ & 22 & 13 \\
\hline $\mathrm{A}<\mathrm{C}$ & 4 & 1 \\
\hline$A>C$ & 9 & 5 \\
\hline \multicolumn{3}{|c|}{ Between subjects $\ddagger$} \\
\hline$A=C$ & 6 & 7 \\
\hline $\mathrm{A}<\mathrm{C}$ & 0 & 0 \\
\hline $\mathrm{A}>\mathrm{C}$ & 1 & 0 \\
\hline
\end{tabular}

* For details of subjects and procedures, see pp. 564-566.

$\uparrow$ Values are the no. of subjects where $\mathrm{A}$ is equal to, less than or greater than $\mathrm{C}$ for $7 \mathrm{~d}$ of dietary assessment. Statistical comparisons made using paired $t$ test at the $P<0.05$ significance.

$\$$ Values are the no. of days where $\mathrm{A}$ is equal to, less than or greater than $\mathrm{C}$ for thirty-five female and nineteen male subjects. Statistical comparisons made using paired $t$ test at the $P<0.05$ significance level.

when compared on any one of the $7 \mathrm{~d}$ of recording, $(r$ values ranged from 0.06 to 0.72 and 0.45 to 0.64 for girls and boys respectively). On $2 \mathrm{~d}$ of the $7 \mathrm{~d}$ the correlation between calculated and analysed intake values for the girls was not significant $(P=0.05)$. Examination of data over the total recording period (paired $t$ test) showed that for fourteen of the fifty-four subjects mean analysed intake values were significantly higher than calculated, and for five subjects mean analysed values were significantly lower than calculated (Table 2). For the group as a whole there was no statistical difference between 


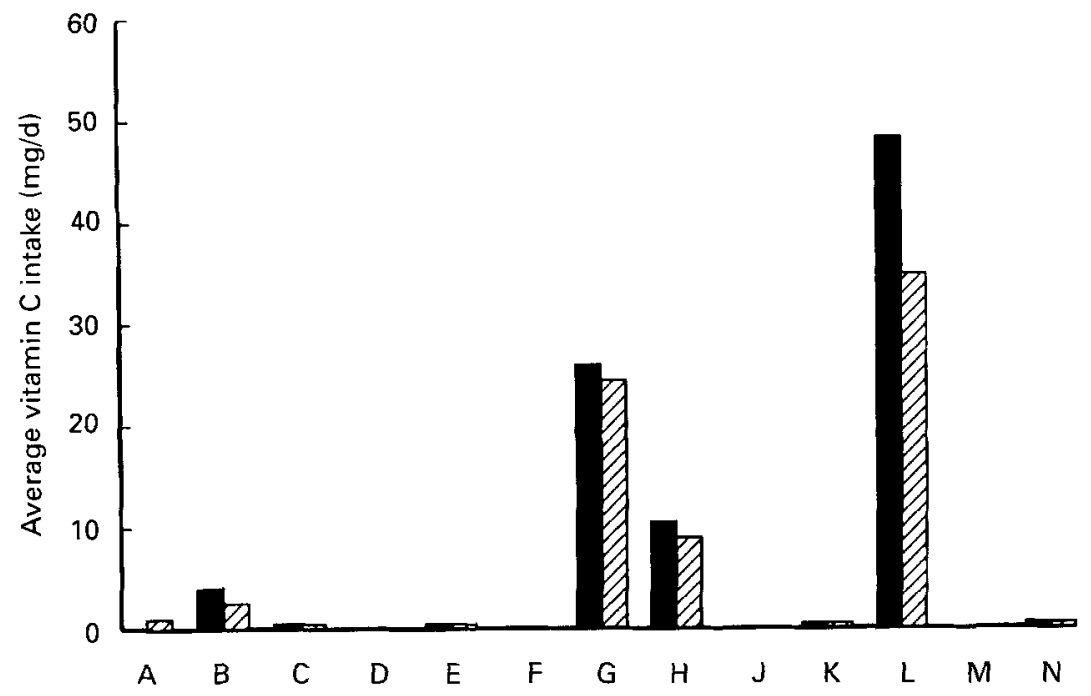

Fig. 2. Contribution of various food groups to calculated vitamin $\mathrm{C}$ intake for male $(\square ; n 19)$ and female ( $\square ; n$ 35) adolescents (13-14 years). A, cereal and cereal products; B, milk and milk products; C, eggs; D, fats and oils; E, meat and meat products; F, fish and fish products; $G$, vegetables; H, fruit; J, nuts; $K$, sugars and preserves; $L$. beverages; $\mathrm{M}$, alcoholic beverages and $\mathrm{N}$, soups, sauces and miscellaneous. For details of subjects and procedures, see pp. $564-566$.

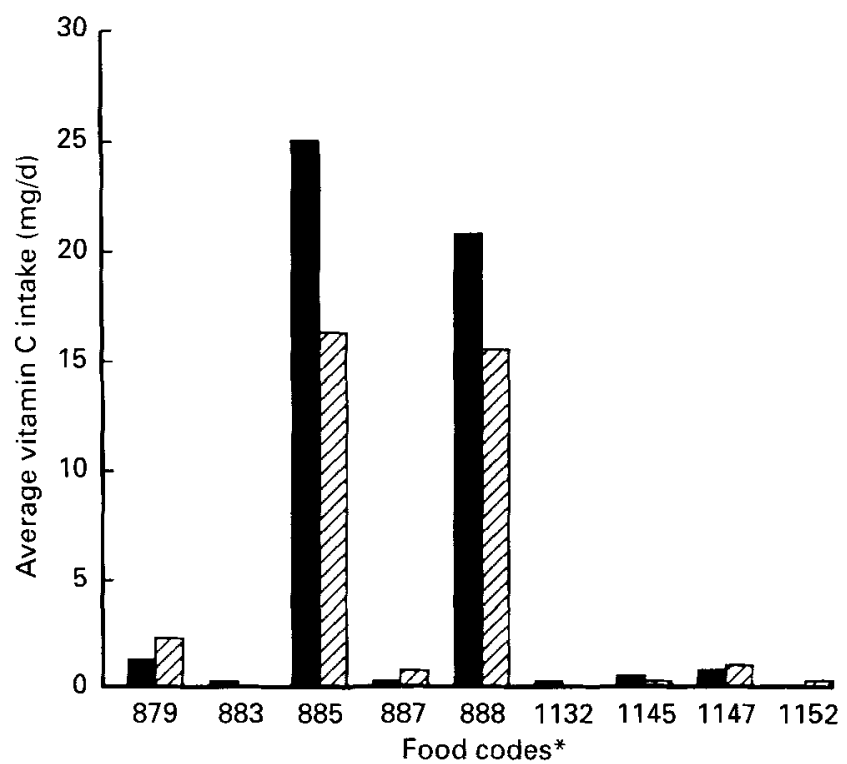

Fig. 3. Contribution of various beverages to calculated vitamin $C$ intake for male $(\square ; n 19)$ and female $(\square ; n 35)$ adolescents (13-14 years). * Mc Cance and Widdowson's The Composition of Foods (Paul \& Southgate, 1978). For details of subjects, see pp. 564 . 
Table 3. Comparison of food group contribution to calculated vitamin $C$ intake, and total daily vitamin $C$ intake for forty individual days with either good agreement (discrepancy $<10 \%$, $\mathrm{n} 20$ ) or poor agreement (discrepancy $>350 \%, \mathrm{n} 20$ ) between analysed and calculated intake values

(Values are means with their standard errors)

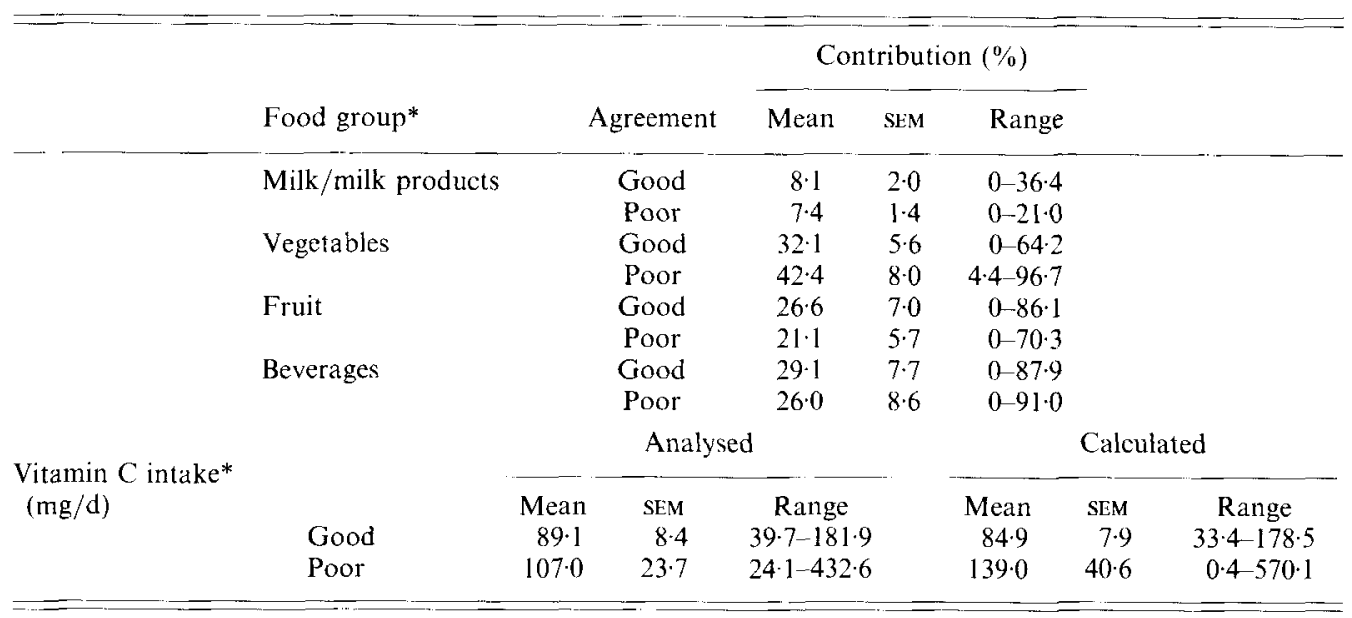

* There were no significant differences between the group of days of good or poor agreement in either mean daily vitamin intake or food group contribution (unpaired $t$ test).

analysed and calculated intakes on any individual day, but when sexes were treated separately the values for females were significantly different on $1 \mathrm{~d}$ of the $7 \mathrm{~d}$ of dietary assessment (Table 2).

\section{Food groups}

The contributions of various food groups to the calculated vitamin $\mathrm{C}$ intake of male and female subjects is shown in Fig. 2. The four major food group sources of the vitamin were milk/milk products, vegetables, fruits and beverages, with beverages contributing approximately $40-50 \%$ of the average daily intake. The two most important beverage sources of vitamin $\mathrm{C}$ were fresh orange juice and blackcurrant squashes (Fig. 3). Vegetable sources provided a further $25-35 \%$ of the daily vitamin $C$, fruits approximately $10-15 \%$ and milk products approximately $5 \%$. Calculated vitamin $\mathrm{C}$ intakes ranged between 0.6 and $725 \%$ of the value obtained by direct analysis of duplicate diets when values were compared on an individual daily basis. Forty separate days of dietary recording were selected to examine the possibility that the magnitude of the discrepancy between calculated and analysed vitamin $C$ intake was related to the food group source of the vitamin. Days of recording were chosen on the basis of a discrepancy of less than $10 \%(n 20)$ or greater than $350 \%(n 20)$. No obvious relationship between the magnitude of the discrepancy and food groups, or total amount of vitamin $C$, consumed that day was found (Table 3 ).

\section{Vitamin C status}

The mean plasma ascorbic acid concentrations for males and females were 81 and 77 $\mu \mathrm{mol} / 1$ respectively. There was no significant difference between sexes but there was a larger variation in the boys (Table 1$)$. Both analysed and calculated vitamin $C$ intake $\left(\log _{10}\right)$ were 
Table 4. Vitamin $C$ intake values for children and adolescents from studies since 1980

\begin{tabular}{|c|c|c|c|c|c|c|c|}
\hline \multirow{2}{*}{$\begin{array}{l}\text { Age } \\
\text { (years) }\end{array}$} & \multicolumn{2}{|l|}{$n$} & \multirow[b]{2}{*}{ Method } & \multicolumn{2}{|c|}{$\begin{array}{l}\text { Intake } \\
\text { (mg/d) }\end{array}$} & \multirow[b]{2}{*}{ Location } & \multirow[b]{2}{*}{ Reference } \\
\hline & q & 3 & & q & $0^{*}$ & & \\
\hline $10-11$ & 158 & 163 & $7 \mathrm{~d}$ weighed & 41 & 43 & $\begin{array}{c}\text { Bristol, Croydon and } \\
\text { Sheffield; England }\end{array}$ & \multirow{3}{*}{ Darke et al. (1980) } \\
\hline $14-15$ & 85 & 92 & $7 \mathrm{~d}$ weighed & 42 & 50 & $\begin{array}{l}\text { Newcastle-upon-Tyne, } \\
\text { England }\end{array}$ & \\
\hline 1415 & 4013 & 390 & $7 \mathrm{~d}$ weighed & 42 & 49 & Birmingham, England J & \\
\hline $9-11$ & 38 & 37 & $7 \mathrm{~d}$ record & 84 & 88 & Dijon, France & \multirow{2}{*}{ Boggio \& Klepping (1981) } \\
\hline $14-16$ & 125 & 73 & $7 \mathrm{~d}$ record & 72 & 88 & Dijon, France & \\
\hline 13 & $137 \quad 1$ & 126 & $24 \mathrm{~h}$ record & 103 & 93 & Tasmania, Australia \} & \multirow{2}{*}{ Woodward et al. (1981) } \\
\hline 14 & 1311 & 129 & $24 \mathrm{~h}$ record & 91 & 122 & Tasmania, Australia $\}$ & \\
\hline $13-15$ & 921 & 103 & $3 \mathrm{~d}$ record & 101 & 119 & Quebec, Canada & Seoane \& Roberge (1983) \\
\hline 12 & 1661 & 158 & $48 \mathrm{~h}$ recall & 95 & 97 & $\begin{array}{l}\text { Helsinki, Kuopio, Oulu, } \\
\text { Tampare and Turku; } \\
\text { Finland }\end{array}$ & Rasanen et al. (1985) \\
\hline $10-11$ & 8148 & 898 & $7 \mathrm{~d}$ weighed & 51 & 51 & Great Britain & $\begin{array}{l}\text { Department of Health } \\
\text { and Social Security (1989) }\end{array}$ \\
\hline $12-13$ & 45 & 45 & $3 \mathrm{~d}$ record & 133 & 126 & Wrexham, Wales & Benton \& Roberts (1988) \\
\hline $11-13$ & $(61)$ & & $7 \mathrm{~d}$ weighed & 28 & 47 & Dundee, Scotland & Crombie et al. (1990) \\
\hline $11-12$ & 67 & 76 & $7 \mathrm{~d}$ weighed & 68 & 67 & London, England & Nelson et al. (1990) \\
\hline \multirow[t]{2}{*}{$13-14$} & 35 & 19 & $7 \mathrm{~d}$ weighed & 75 & 121 & Norwich, England & Present study \\
\hline & & & $\begin{array}{l}7 \mathrm{~d} \text { direct } \\
\text { analysis }\end{array}$ & 84 & 121 & & \\
\hline
\end{tabular}

significantly correlated to plasma AA for male subjects (analysed $r 0.59, P<0.01$; calculated $r 0.63, P<0.01)$. However, for female subjects only the correlation between analysed intake $\left(\log _{10}\right)$ and plasma AA was significant $(P<0.05)$ and the $r$ value $(0.33)$ indicated a poorer relationship compared with male subjects.

\section{DISCUSSION}

Since 1980 there have been several reports in the literature of vitamin $C$ intakes in children and adolescents (Table 4). In each of these studies intakes were based on calculations using food composition tables and none of them provided any information on the vitamin $C$ status of the subjects. In view of the many studies which rely upon food composition information for the assessment of nutrient intakes, it is important to determine the likely degree of accuracy of such studies for the prediction of actual intake. This is particularly important for vitamin $\mathrm{C}$, a highly labile vitamin which can vary markedly in content between different samples of the same food due to such factors as variety, cooking procedures, storage, maturity and level of fortification. It has been suggested that average values given in the food tables are not sufficiently accurate for assessing dietary intake of this vitamin (Black et al. 1983). Nevertheless, the practice of using food composition tables for the assessment of vitamin $\mathrm{C}$ intake is commonplace. In the present study a $7 \mathrm{~d}$ weighed record method of dietary assessment using food composition tables for the calculation of vitamin $\mathrm{C}$ intake was compared with direct analysis of duplicate diets. The small losses of vitamin $\mathrm{C}$ from samples of mixed diets, analysed immediately after preparation and again 
after storage overnight and up to $6 \mathrm{~d}$ at $-18^{\circ}$, suggested that the analysed values obtained in the study were realistic of the actual amounts present in the duplicate diets. The degree of discrepancy between mean $7 \mathrm{~d}$ and between individual daily calculated and analysed values was determined and consideration was given as to whether any particular food group was especially contributing to major discrepancies.

Weighed dietary records and duplicate diet collections were made every 6 th day over a period of 7 weeks, thus all days of the week were taken into consideration. Nelson et al. (1989) have suggested about 6-12 d are usually needed to obtain a reasonably precise estimate of long-term vitamin $\mathrm{C}$ intake since there appear to be large daily fluctuations. The method of recording at intervals over a longer period of collection was chosen in view of evidence that the accuracy of record keeping can deteriorate over two consecutive days recording and that useable records during days 5-7 are sometimes only obtained from more highly educated subjects (Gibson, 1990a). There is also evidence that the added burden of duplicate diet collection can result in a decrease in recorded energy intake by as much as $20 \%$ (Gibson, 1990 $a$ ) and it was considered that seven consecutive days of collection may further reduce the accuracy of our estimate of true intake. In addition, discussion with parents and subjects indicated that compliance would be better with the chosen method of recording/collection. The potential for under-recording intake, changing diet during the period of recording and possible variation by day, week or season, and statistical considerations associated with variation in intake has been well reviewed by Bingham (1987) and Borrelli (1990) respectively. The possible extent of under-recording of total food intake in the present study was assessed using mean daily analysed energy intake values obtained in the present study and estimates of daily energy expenditure for 13-14 year olds of similar median height and weight as published in the report of a joint Food and Agriculture Organization/World Health Organization/United Nations University Expert Committee on energy and protein requirements (1985). Assuming a light level of activity (going to school, sitting, standing, moving around, social activity, washing and play), gross daily energy costs have been estimated to be $1.6 \times$ basal metabolic rate $(\mathrm{BMR} ; 6120 \mathrm{~kJ})=$ $9792 \mathrm{~kJ}$ for boys and $1.5 \times \mathrm{BMR}(5600 \mathrm{~kJ})=8400 \mathrm{~kJ}$ for girls. Comparison of these values with analysed energy intakes obtained in the present study indicated that the energy intakes for boys and girls were 6 and 12\% lower respectively, than their estimated daily energy expenditure. Using other estimates of daily energy expenditure presented by the Department of Health and Social Security (1991), similar estimates for subjects were derived (boys, $1.56 \times$ BMR $(6450 \mathrm{~kJ} / \mathrm{d})=10062 \mathrm{~kJ} / \mathrm{d}$; girls, $1.48 \times \mathrm{BMR}(5420 \mathrm{~kJ} / \mathrm{d})=$ $8022 \mathrm{~kJ} / \mathrm{d}$ ). It appears, therefore, that there was no gross underestimation of habitual energy intake. The discrepancy would, of course, be higher if subjects had spent significant amounts of time involved in moderate and heavy activities, but it cannot be assumed that any under-recording influenced all food groups equally and no attempt was made to adjust the vitamin $C$ intake values presented in the present paper.

The mean vitamin $C$ intake values obtained for boys in the present study (analysed 121.4, calculated $121.2 \mathrm{mg} / \mathrm{d})$ were at the upper end of the range $(43-126 \mathrm{mg} / \mathrm{d})$ published in several previous studies of 9-13 year olds, whilst the intake for females (analysed 84.2, calculated $74.8 \mathrm{mg} / \mathrm{d}$ ) was 'middle of the range' of studies quoted (Table 4 ). The most important sources of vitamin $\mathrm{C}$ in terms of percentage contribution to intake were fresh orange juice and blackcurrant squashes which supplied in excess of $40 \%$ of the average daily vitamin $\mathrm{C}$ (Fig. 3).

Despite large discrepancies between analysed and calculated intake values within any one individual on any $1 \mathrm{~d}$, and the fact that in some instances analysed and calculated data (for the group as a whole) on any $1 \mathrm{~d}$ was not significantly correlated, the overall analysed and calculated mean values for the $7 \mathrm{~d}$ recording/duplicate diet collection were not significantly 
different from each other. There was also a reasonably good correlation between $7 \mathrm{~d}$ mean analysed and calculated values for both male and female subjects. It would appear, therefore, that calculated vitamin $C$ intakes for the group of subjects assessed over $7 \mathrm{~d}$, gave a good indication of actual intakes as judged by prompt direct analysis of duplicate diets. As a cautionary note, however, it should be recognised that there was a statistical difference between analysed and calculated intakes for approximately one-third of the subjects when subjects were examined individually over the $7 \mathrm{~d}$ of dietary assessment, indicating the potential unreliability of calculated data used on an individual basis. In addition, the relationship between the more usual method of seven consecutive days of dietary assessment and measurements made every 6th day for 7 weeks, as described in the present study, requires further investigation. It was also apparent, from consideration of percentage contribution to vitamin $C$ intake from major food sources, that large discrepancies between analysed and calculated values could not be accounted for on a food group basis.

There is very little recent information on vitamin $\mathbf{C}$ status during adolescence when individuals are experiencing or are commencing a period of rapid growth and when requirements may be higher. The most commonly used methods for the assessment of vitamin $\mathrm{C}$ status are leucocyte and serum/plasma AA concentration. Leucocyte concentrations are considered to reflect body stores while plasma AA is more easily influenced by recent dietary intake (VanderJagt et al. 1989). Nevertheless, within the usual range of intakes the plasma level is generally proportional to body stores provided that blood samples are taken after an adequate fasting period (Read, 1987). In the present study plasma AA concentration measured promptly in fasting $(12-15 \mathrm{~h})$ blood samples was used as an index of status.

A linear relationship between dietary vitamin $\mathrm{C}$ intake and plasma AA concentration has been found previously in the elderly over the concentration range $17-80 \mu \mathrm{mol} / 1$ (Newton et al. 1983; Thurnham, 1985). Plasma AA tended to plateau at about $80 \mu \mathrm{mol} / 1$ in this agegroup, corresponding to an intake of about $100 \mathrm{mg} / \mathrm{d}$. In adult populations generally it is reported that serum concentrations rarely exceed $80 \mu \mathrm{mol} / 1$ because the renal clearance of the vitamin rises sharply with daily intakes greater than $100 \mathrm{mg} / \mathrm{d}$ (Friedman et al. 1940). In the present study of 13-14 year olds, twenty-five of the fifty-four subjects had plasma AA concentrations of $81-90 \mu \mathrm{mol} / \mathrm{l}$, six subjects $91-95 \mu \mathrm{mol} / \mathrm{l}$, three subjects approximately $100 \mu \mathrm{mol} / 1$ and one subject approximately $200 \mu \mathrm{mol} / \mathrm{l}$. These plasma AA values corresponded to mean analysed intakes of $77,90,100$ and $246 \mathrm{mg} / \mathrm{d}$ respectively. The plasma AA concentrations for 13-14 year olds obtained in the present study were much higher than those obtained in several other studies of 12-18 year olds performed in the 1940 s and presented in a thorough review of the area by Irwin \& Hutchins (1976). In these early studies plasma AA values of approximately $50 \mu \mathrm{mol} / 1$ for an intake of about $80 \mathrm{mg} / \mathrm{d}$ are quoted for this age-group. The reason for this difference is unclear but it is possible that the prompt analysis, coupled with the use of more recently developed sensitive analytical techniques, has resulted in improved measurement of the vitamin compared with techniques employed in earlier investigations. In addition, plasma AA concentrations obtained in our laboratory for healthy adult (20-64 years, $n 46$; mean plasma AA 50 (range $3-93) \mu \mathrm{mol} / 1$ ) and elderly (64-74 years, $n$ 74; mean plasma AA 40 (range $4-89$ ) $\mu \mathrm{mol} / \mathrm{l}$ ) populations (S. Southon, unpublished results) indicated that the high values obtained for the adolescents in the present study were not an artifact due to methodological factors.

The subject with a plasma AA concentration of $200 \mu \mathrm{mol} / 1$ and an average daily intake of $246 \mathrm{mg} / \mathrm{d}$ was the only subject who supplemented their diet with a significant amount of vitamin C. Individuals who routinely consumed supplements were not excluded from the study population since we were interested in determining the relationship between habitual intake of the nutrient and status, as judged by plasma AA levels. The supplement was taken 
daily (morning) and, as stated previously, the subject fasted for $12-15 \mathrm{~h}$ overnight before a blood sample was taken. It may not necessarily be true, therefore, that plasma AA levels cannot be used to identify persons regularly consuming excessive amounts of the vitamin (Gibson, 1990 b), at least in the case of younger individuals where there may be physiological differences in the metabolism of vitamin $\mathrm{C}$.

Further evidence for a difference in vitamin $\mathrm{C}$ metabolism in younger individuals is indicated by the lack of a sex difference in plasma AA concentration. Adult women appear to have higher plasma AA concentrations than men on similar intakes, but such sex differences are not apparent before adolescence (Dodds, 1969) and indeed the plasma AA concentrations of boys and girls in the present study were not significantly different. However, mean analysed or calculated vitamin $\mathrm{C}$ intake was significantly lower in the female subjects whilst plasma AA values were similar to the males. This may be indicative of the emergence of the sex difference which becomes more apparent in later life.

There was also a possible sex difference relating to the relationship between vitamin $C$ intake and status in the present study. There was a significant relationship between both calculated and analysed intakes and plasma AA in males but in females there was no relationship to calculated intake and only a very poor relationship to analysed intake. The most likely explanation for this possible difference is the wider range of intakes and plasma AA values obtained for males, particularly at the upper end of the range, whilst for either sex there were few low intake or plasma AA values. It is generally assumed that the relationship between vitamin $\mathrm{C}$ intake and status reaches a plateau at an intake of approximately $100 \mathrm{mg} / \mathrm{d}$ and a fasting plasma AA of approximately $80 \mu \mathrm{mol} / 1$. It appears from the present study, however, that in certain individuals habitual intakes in excess of this amount may result in a further increase in plasma AA concentration. This is supported by a study performed by Schorah et al. (1981) which showed that a daily supplement of $1 \mathrm{~g}$ vitamin $\mathrm{C}$ given to elderly subjects for $60 \mathrm{~d}$ could increase the fasting plasma AA concentration up to $151 \mu \mathrm{mol} / \mathrm{l}$.

In conclusion, the present study indicated that vitamin $\mathrm{C}$ intakes for groups calculated from food composition tables gives a reasonable estimate of actual intake, as judged by prompt analysis of duplicate diets. However, findings presented here clearly demonstrate the unreliability of calculated values used on an individual basis. In general, the adolescents taking part in the present study had vitamin C intakes well in excess of the current RNI of $40 \mathrm{mg}$ (Department of Health and Social Security, 1991) and status, as judged by plasma AA concentration, was extremely good and was well above the value of $11-22 \mu \mathrm{mol} / 1$ used to indicate moderate risk of deficiency (Gibson, 1990 b). A stronger relationship between vitamin $\mathrm{C}$ intake and plasma $\mathrm{AA}$ was observed in males, although this could be a misleading mathematical artifact as both intake and status values showed a wider range compared with females.

This work is supported by the UK Department of Education \& Science (DES), the UK Ministry of Agriculture, Fisheries and Food (MAFF) and the Vitamin Forum. The authors thank Heather Sarsby, Zoe Piper, Wendy Lee, Jane Lumb and Joanne Belsten for their invaluable assistance with this study and Dr Julia Leach for taking blood samples from the subjects. Special thanks also to the subjects themselves, their parents, teachers and the catering staff at the two schools.

\section{REFERENCES}

Bates, C. J. (1981). The function of vitamin C in man. In Vitamin C (Ascorbic Acid), pp. 1-22 [J. N. Counsell and D. H. Hornig, editors]. London: Applied Science Publishers.

Behrens, W. A. \& Madere, R. (1987). A highly sensitive high-performance liquid chromatography method for the 
estimation of ascorbic and dehydroascorbic acid in tissues, biological fluids and foods. Analytical Biochemistry. $165,102-107$

Benton, D. \& Roberts, G. (1988). Effect of vitamin and mineral supplementation on intelligence of a sample of schoolchildren. Lancet i, 140-143.

Black, A. E., Asby, D. R., Day, K. E., Bates, C. J. \& Paul, A. A. (1983). Analytical versus food table values of vitamin $\mathrm{C}$ in foods: the effect on calculated vitamin $\mathrm{C}$ intake of elderly subjects. Human Nutrition: Applied Nutrition 37A, 9-22.

Black, A. E., Ravenscroft, C. \& Sims, A. J. (1984). THE NACNE REPORT: are the dietary goals realistic? Comparisons with the dietary patterns of dieticians. Human Nutrition: Applied Nutrition 38A, 165-179.

Bingham, S. A. (1987). The dietary assessment of individuals; methods, accuracy, new techniques and recommendations. Nutrition Abstracts and Reviews 57, 705-742.

Boggio, V. \& Klepping, J. (1981). Characteristics of the food intake of children. Archives Francaises de Pediatrie 38, $679-686$.

Borrelli, R. (1990). Collection of food intake data : a reappraisal of criteria for judging the methods. British Journal of Nutrition 63, $411-417$.

Crawley, H. (1988). Food Portion Sizes. London: H.M. Stationery Office.

Crombie, I. K., Todman, J., McNeil, G., Florey, C. V., Menzies, I. \& Kennedy, R. A. (1990). Effect of vitamin and mineral supplementation on verbal and non-verbal reasoning of schoolchildren. Lancet $335,744-747$.

Darke, S. J., Disselduff, M. M. \& Try, G. P. (1980). Frequency distributions of mean daily intakes of food energy and selected nutrients obtained during nutrition surveys of different groups of people in Great Britain between 1968 and 1971. British Journal of Nutrition 44, 243-252.

Department of Health and Social Security (1989). The Diets of British Schoolchildren. Report on Health and Social Subjects no. 36. London: H.M. Stationery Office.

Department of Health and Social Security (1991). Dietary Reference Values for Food Energy and Nutrients for the United Kingdom. Report on Health and Social Subjects no. 41. London: H.M. Stationery Office.

Dodds, M. L. (1969). Sex as a factor in blood levels of ascorbic acid. Joumal of the American Dietetic Association 54, 32-33.

Food and Agriculture Organization/World Health Organization/United Nations University Expert Committee (1985). Energy and Protein Requirements. Technical Report Series no. 724, pp. 71-112. Geneva: World Health Organisation.

Frei, B., Stocker, R. \& Ames, B. N. (1988). Antioxidant defences and lipid peroxidation in human blood plasma. Proceedings of the National Academy of Sciences, USA 85, 9748-9752.

Friedman, G. J., Sherry, S. \& Ralli, E. P. (1940). Mechanism of excretion of vitamin C by the human kidney at low and normal plasma levels of ascorbic acid. Journal of Clinical Investigation 19, 685-689.

Gibson, R. S. (1990a). Principles of Nutritional Assessment, pp. 122-123. Oxford, New York: University Press.

Gibson, R. S. (1990 b). Principles of Nutritional Assessment, pp. 414-416. Oxford, New York: Oxford University Press.

Holland, B., Unwin, I. D. \& Buss, D. H. (1988). Cereals \& Cereal Products. The 3rd Supplement to Mc Cance \& Widdowson's The Composition of Foods. Cambridge: RSC/MAFF.

Holland, B., Unwin, I. D. \& Buss, D. H. (1989). Milk Products and Eggs. The 4th Supplenent to McCance \& Widdowson's The Composition of Foods. Cambridge: RSC/MAFF.

Hughes, R. E. (1956). The use of homocysteine in the estimation of dehydroascorbic acid. Biochemical Journal 64 , $203-208$.

Irwin, M. I. \& Hutchins, B. K. (1976). A conspectus of research on vitamin C requirements of man. Journal of Nutrition 106, 823-879.

Jacob, R. A., Otradovec, C. L., Russell, R. M., Munro, H. N., Hartz, S. C., McGandy, R. B., Morrow, F. D. \& Sadowski, J. A. (1988). Vitamin C status and nutrient interactions in a healthy elderly population. American Journal of Cinical Nutrition 48, 1436-1442.

Miller, D. S. \& Payne, P. R. (1959). A ballistic bomb calorimeter. British Journal of Nutrition 13, 501-508.

Nelson, M., Black, A. E., Morris, J. A. \& Cole, T. J. (1989). Between- and within-subject variation in nutrient intake from infancy to old age: estimating the number of days required to rank dietary intakes with desired precision. American Journal of Clinical Nutrition 50, 155-167.

Nelson, M., Nasmith, D. J., Burley, V., Gatenby, S. \& Geddes, N. (1990). Nutrient intakes, vitamin-mineral supplementation, and intelligence in British schoolchildren. British Journal of Nutrition 64, 13-22.

Newton, H. M. V., Morgan, D. B., Schorah, C. V. \& Hullins, R. P. (1983). Relation between intake and plasma concentration of vitamin $\mathrm{C}$ in elderly women. British Medical Journal 287, 1429

Paul, A. A. \& Southgate, D. A. T. (1978). Mc Cance \& Widdowson's The Composition of Foods, 4th ed. London: H.M. Stationery Office.

Rasanen, L., Ahola, M., Kara, R. \& Uhari, M. (1985). Atherosclerosis precursors in Finnish children and adolescents. VIII. Food consumption and nutrient intakes. Acta Paediatrica Scandinavica 318, Suppl. $135-153$.

Read, R. S. D. (1987). Vitamin C. Journal of Food and Nutrition 44, 9-35.

Sauberlich, H. E. (1981). Ascorbic Acid (Vitamin C). Clinics in Laboratory Medicine 1, 673-684.

Seoane, N. A. \& Roberge, A. G. (1983). Calorie and nutrient intake of adolescents in the Quebec city region. Canadian Journal of Public Health 74, 110-116. 
Schorah, C. J., Tormey, W. P., Brooks, G. H., Robertshaw, A. M., Young, G. A., Talukder, R. \& Kelly, J. F. (1981). The effect of vitamin C supplements on body weight, serum proteins, and general health of an elderly population. American Journal of Clinical Nutrition 34, 871-876.

Tan, S. P., Wenlock, R. W. \& Buss, D. H. (1985). Immigrant Foods. The 2nd Supplement to McCance \& Widdowson's The Composition of Foods. London: H.M. Stationery Office.

Thomas, B. (1988). Manual of Dietetic Practice, pp. 44-49. London: Blackwell Scientific Publications.

Thurnham, D. I. (1985). The interpretation of biochemical measurements of vitamin status in the elderly. In Vitamin Deficiency in the Elderly, pp. 56-58. London: Blackwell Scientific Publications.

VanderJagt, D. J., Garry, P. J. \& Bhagavan, H. N. (1987). Ascorbic acid intake and plasma levels in health elderly people. American Journal of Clinical Nutrition 46, 290-294.

VanderJagt, D. J., Garry, P. J. \& Bhagavan, H. N. (1989). Ascorbate and dehydroascorbate: distribution in mononuclear cells of healthy elderly people. American Journal of Clinical Nutrition 49, 511-516.

Wiles, S. J., Nettleton, P. A., Black, A. E. \& Paul, A. A. (1980). The nutrient composition of some cooked dishes eaten in Britain: a supplementary food composition table. Journal of Human Nutrition 34, 189-223.

Woodward, D. R., Lynch, P. P., Waters, M. J., Maclean, A. R., Ruddock, W. E., Ratjai, J. W. \& Lemoh, J. N. (1981). Dietary studies on Tasmanian high school students: intakes of energy and nutrients. Australian Paediatric Journal 17, 196-201. 